\title{
A model of the meat waste management
}

\author{
Zygmunt Kowalski, Kinga Krupa-Żuczek \\ Institute of Chemistry and Inorganic Technology, Cracow University of Technology, ul. Warszawska 24, 31-155 Kraków, \\ Poland, e-mail: zkow@chemia.pk.edu.pl
}

\begin{abstract}
The European Union produces about 18 million tons of waste from meat industry per year. The real danger of the BSE disease caused a necessity of looking for a new alternative solution of meat waste management. The proposed solution of meat industry waste management would create meat production waste free with the use of the cleaner production method. Cleaner production includes: pollution prevention, reduction of the source, recovery of materials and energy (for example: the recovery of blood plasma and protein hydrolisate from bone sludge) and their recycling. The thermal processing of meat industrial waste (bone sludge, meat-bone meal and odour) is anticipated, too. Ashes from meat calcining have the phosphorus content close to its concentration, of the typical phosphoric raw materials. That confirmed the possibility of using such ashes as the substitute of phosphoric raw materials. The target model of waste free meat waste management included the results of the implemented and current research.
\end{abstract}

Keywords: meat waste, cleaner production, waste management, model solution.

Presented at VII Conference Wasteless Technologies and Waste Management in Chemical Industry and Agriculture, Międzyzdroje, 12 - 15 June, 2007.

\section{INTRODUCTION}

Europe generates of about $18 \mathrm{mln} \mathrm{t} / \mathrm{year}$ of meat wastes that should be utilized, according to the appropriate UE directive. In Poland the amount of this kind of wastes reaches about $1 \mathrm{mln} \mathrm{t} / \mathrm{year}$. Up to now most of them were converted to the meat-bone meal MBM used as feed additive. The appearing of the BSE resulted in the problem with MBM application. The quantity of meat-bone meal used currently in Poland for soil improving is estimated to be $400000 \mathrm{t}$ / year $^{1,2}$. The animal wastes processing into the meat-bone meal still remains the basic methods of their utilization, due to a very large quantity of meat factories existing in Poland and in Europe. Therefore, the MBM production should be transformed into cleaner technology ${ }^{2}$. It is important that meat waste processing resulted in bio fuel (the animal fat) that substitutes the conventional energy source ${ }^{1-3}$.

Production of calcium phosphate is recommended by the UE for the utilisation of bone waste. This process contains two technological operations, the first is degreasing of a bone in a hot water and the second one is to dissolve the bone in hydrochloric acid for at least two days. Next the obtained solution is treated with calcium oxide to precipitate calcium phosphate at $\mathrm{pH}=4-7$. This sludge is dried by air at 270 $-325^{\circ} \mathrm{C}$. This process would be rather impracticable from a technological point of view 1 .

The presented paper describes the model solution of meat waste management that could convert meat industry into the waste-free one with the use of cleaner technology method ${ }^{4,5}$. The implemented technologies allowed processing by-products from meat industry that could be next re-used in meat industry due to the use of the in- and off-process recycling. Energy recovery from meat waste is possible, too. The thermal processing of meat and bone is developed. This resulted in the production of the ash with the properties allowing to use it for phosphate compounds manufacturing as the substitute of natural phosphoric raw material ${ }^{6-8}$. New technologies of waste processing enable avoiding problems with their expensive utilization. The decrease in the utilization costs permits to define the new proposed technologies as the best available techniques, not entailing the excessive BATNEEC ${ }^{6}$ costs.

\section{CLEANER TECHNOLOGIES - TO PREVENT THE MEAT WASTE FORMATION}

Cleaner technology is a strategy of a continuous pollution prevention related to production processes, products and services. The „Cleaner production” concept applies to such production management that prevents the influence on natural environment in all phases of their life cycle - from the input of raw materials to the final storage of the spent prod$\mathrm{uct}^{4,5,9}$. Cleaner production techniques include protection of natural resources of raw materials and energy, elimination of toxic raw materials, reduction of the quantity and toxicity of all types of the waste. The most important method of the

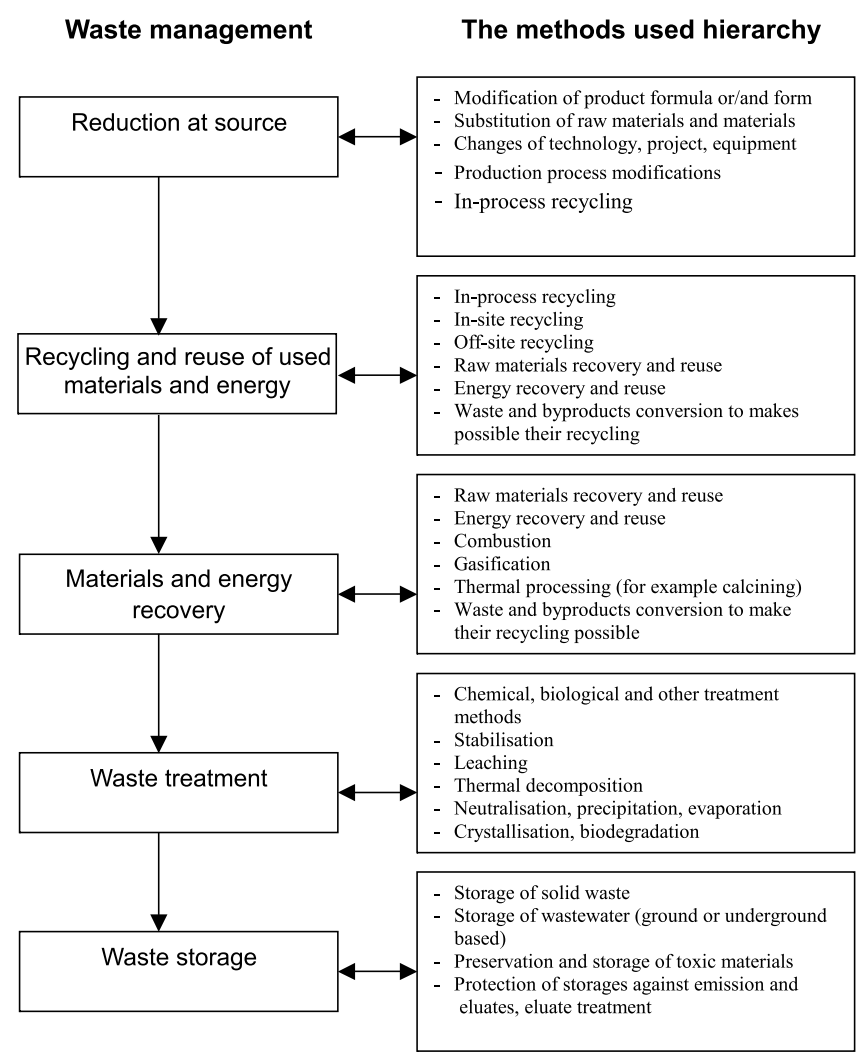

Figure 1. The hierarchy of pollution prevention options and the waste management techniques 
Table 1. The balance sheet of meat waste shown on the example of a meat factory in Poland

\begin{tabular}{|c|c|c|c|c|c|c|}
\hline \multirow[b]{2}{*}{ Type of waste } & \multicolumn{3}{|c|}{ Quantity [per 1 year] - meat factory } & \multicolumn{3}{|c|}{ Quantity [per 1 year] - Poland } \\
\hline & $\begin{array}{l}\text { Meat } \\
\text { factory } \\
\text { [ton] }\end{array}$ & $\begin{array}{c}\text { Equal } \\
\text { [GJ] }\end{array}$ & $\begin{array}{c}\text { Equal } \\
\text { [mln of } \mathrm{cm} \text { ] of } \\
\text { natural gas }\end{array}$ & $\begin{array}{l}\text { Poland } \\
\text { [ton] }\end{array}$ & $\begin{array}{c}\text { Equal } \\
\text { [GJ] }\end{array}$ & $\begin{array}{c}\text { Equal } \\
\text { [mln of } \mathrm{cm} \text { ] of } \\
\text { natural gas }\end{array}$ \\
\hline Wasted animal tissue (soft) & 432 & & & 14388 & & \\
\hline $\begin{array}{l}\text { Raw materials and products not fit for } \\
\text { processing }\end{array}$ & 38 & & & 1281 & & \\
\hline Animal fat (from waste) & 1354 & 52815 & 1.57 & 45141 & 1760487 & 52 \\
\hline Bones after processing & 3761 & & & 125356 & & \\
\hline $\begin{array}{l}\text { Wasted an imal tissue; intestine content and } \\
\text { haslets }\end{array}$ & 1200 & & & 40000 & & \\
\hline Wasted animal tissue ; bristle & 240 & & & 8000 & & \\
\hline Blood & 560 & & & 18667 & & \\
\hline Postflotation waste & 11475 & & & 382500 & & \\
\hline Feed system content & 2745 & & & 91493 & & \\
\hline By-product of the slaughter process & 5733 & & & 191090 & & \\
\hline Hoofs, horns, nails and others & 788 & & & 26280 & & \\
\hline Total & 28326 & & & 944196 & & \\
\hline
\end{tabular}

cleaner production is pollution prevention. The particular pollution prevention option form the hierarchy presented in Figure 1.

The quantities of waste obtained in particular meat factories are diversified, depending on the raw materials used, technology level, equipment and many others factors, especially production capacity. Table 1 listed the quantities of solid waste produced in one of the most modern Polish meat factories that are next converted into the country scale $\mathbf{1 0}^{\mathbf{1 0}}$. This estimation is rather underrated and practical waste quantities are on the country scale higher because especially the lower meat factories aren't so modern and produce relatively more waste.
At present, according to ${ }^{11-14}$ the used waste management method depends on the categorisation of specific meat waste. The qualification to particular categories resulted from the hazard created with the given meat waste.

Waste from meat industry, such as bones and all the elements of the bodies of animals suspected of the BSE infection belong to the I - high-risk category. Only one of the neutralization methods of these wastes is thermal processing at controlled temperature, not lower than $1123 \mathrm{~K}$ for minimum $2 \mathrm{~s}$. The II category material presented the animal byproducts (droppings, contents of alimentary canal), animal material collected during the processing of liquid wastes from the slaughterhouse and the products of animal origins,

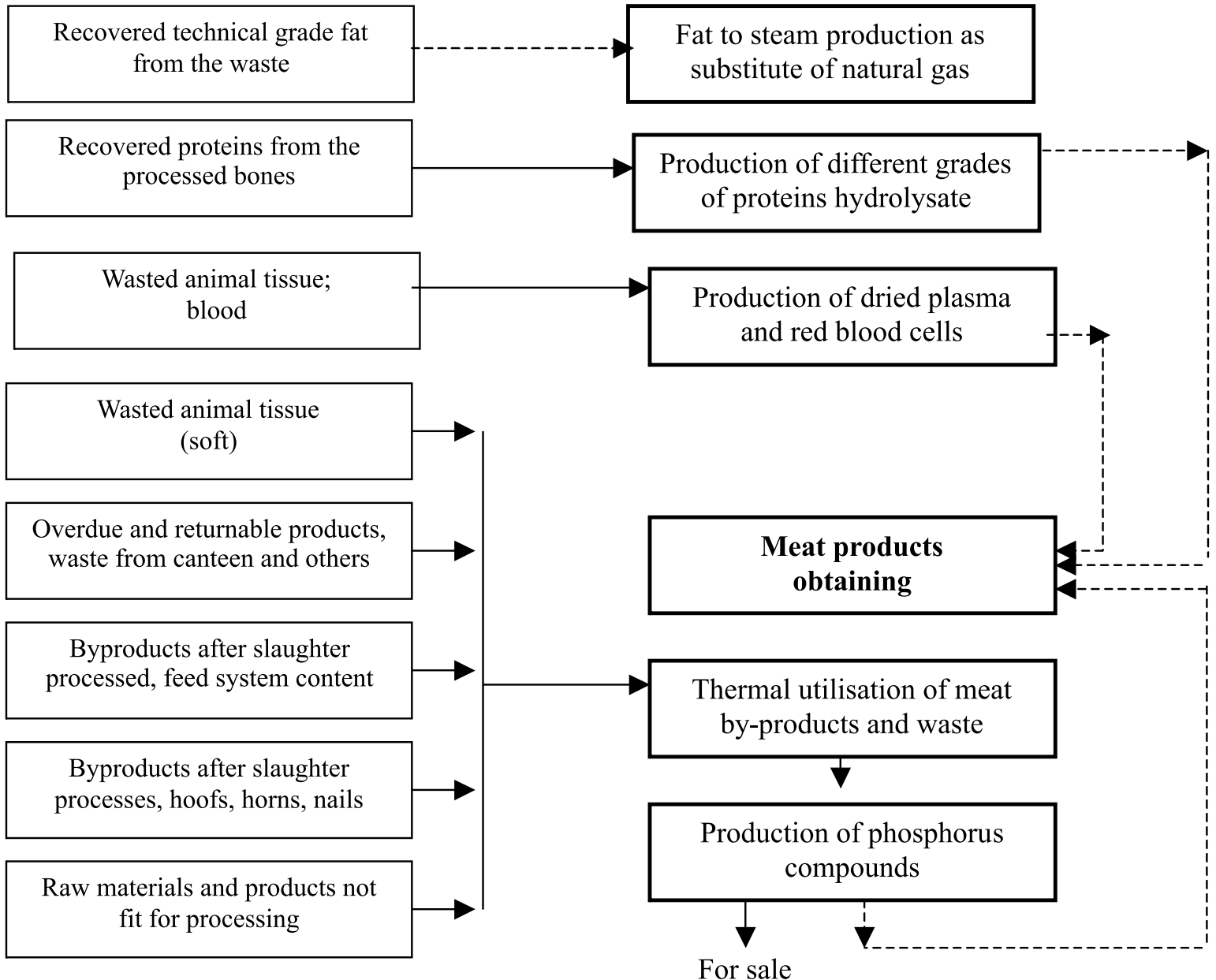

Figure 2. The target model of meat waste management (recycling, energy recovery from waste and the reuse of the processed waste and by-products marked with dashed lines) 
including the residues of veterinary medicine. The wastes of these categories have to be collected and utilized by the combustion in incinerating plants. Melting fat is used as the fuel (a substitute of the natural gas and the protein materials are processed further and re-used in meat industry or as the component of animal foods or organic fertilizers. Bone mud that is deproteinised and the degreased bones, skin, hoofs, horns, pork bristle, feathers, the blood obtained from animals different from ruminants, elements of slaughtered animals fit or not for people consumption that do not have the diseases transferred onto people, belong to the III category of waste. These have to be thermally utilized or processed into the feed component, biogas or compost.

\section{A CHARACTERISTIC OF MEAT WASTE AND A PRO- POSAL OF ITS UTILISATION}

The preliminary model of meat waste management contained two variants. Variant I (Figure 2) could be used in bigger meat factories where by-product processing and their reuse in meat production would be profitable.

In terms of capacity it would also be possible to use the wasted fat as fuel and thermal utilisation of bone waste and all the types of other post animal waste ${ }^{7}$. This waste has (even after degreasing some of them) rather high combustible value $(8-30 \mathrm{MJ} / \mathrm{kg})^{7,15}$. The ash from thermal utilization contains mostly hydroxyapatite $\left.\mathrm{Ca}_{5}\left(\mathrm{PO}_{4}\right)_{3}\right) \mathrm{OH}$ that would be used as raw materials in the production of phosphoric acid and other phosphoric salts in chemical factories.
Variant II (Table 2) proposes thermal utilisation of meat bone meal and the use of the produced ash as raw material in the phosphoric acid production.

Below are presented the implemented and developed solutions of meat waste and the by-products management.

\section{Utilisation of animal blood}

In food production different blood plasma with different concentrations is used; liquid plasma (to $91 \%$ of water), plasma concentrate (to $79 \%$ of water) and dried powdered plasma ( $5-7 \%$ of water). Blood is, in terms of nutrient value, one of most valuable by-products. Their content in the organism of slaughtered animals in proportion to the total weight $4,6 \%$ for pigs and $8 \%$ for cattle ${ }^{\mathbf{1 6}, 17}$.

Basic blood components, finding their practical application, are as follows:

- serum (blood without red cells) - used in food industry

- blood serum, plasma (serum without fibrinogen that was eliminated in blood defibrillation process resulted in the separation of red cells slurry from the blood) contain about $0.7 \%$ less of proteins than the serum - used in food industry - globine (the colourless part of haemoglobin. Together with hem and strome they are the red cells components. Hem is $4 \%$ part of the globine mass) - used in food industry

- hem - used for the chemical synthesis of different compounds, used as a dye of meat substitutes.

The use of blood is limited due to its high instability, high content of water, potential hazard of disease transfer, red colour, specific taste and smell.

Anti coagulator sodium citrate $167 \mathrm{~kg}$
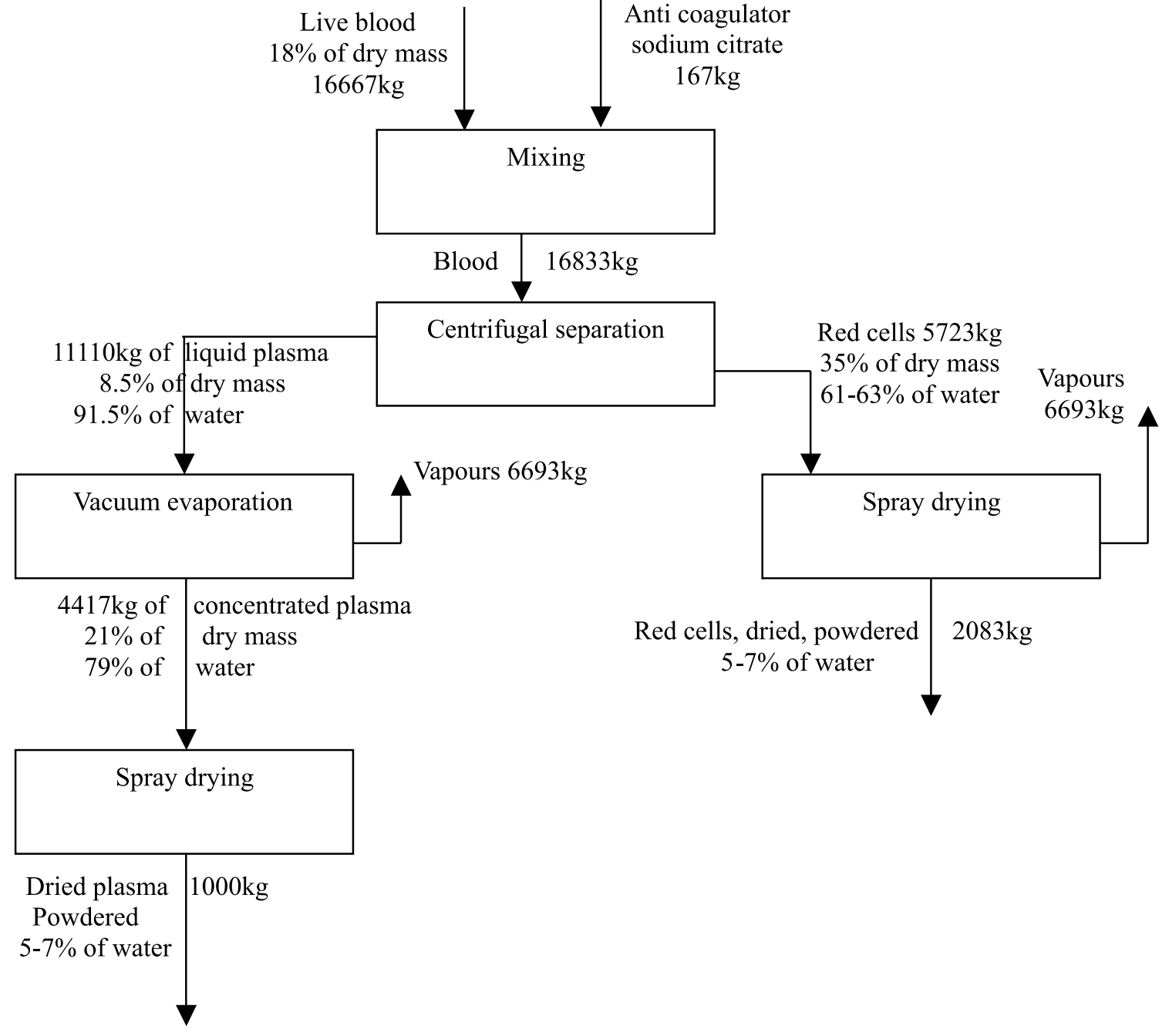

Figure 3. The flow sheet of the dried plasma and dried red cells production from animal blood 
Centrifugal separation is a typical method of blood separation into plasma (colourless serum) and the red cells slurry (Figure 3). The density of red cells is about $0.046-0.073$ $\mathrm{g} / \mathrm{cm}^{3}$ higher than the plasma density. This method allows one to obtain on the average $55-60 \%$ of slightly coloured plasma. The rest is the red cells slurry. The liquid plasma could be evaporated with the vacuum evaporator and dried with a spray dryer.

\section{Production of proteins hydrolysate and gelatine}

Proteins hydrolysate is a mixture of peptides obtained in the process of hydrolysis of natural proteins. It is used mostly as raw material in food and cosmetic industry and for technical purposes, too ${ }^{\mathbf{1 8 - 2 0}}$. The technical grade hydrolysates are produced from the meat waste (skin, hair, blood, milk), fish meat, eggs, oil seeds.

Bones after the slaughter process are also used as the raw material for the production of proteins hydrolysate. After grinding the mixture of bone pulp and water with a low addition of lactic acid, it is heated at $125-135^{\circ} \mathrm{C}$ under the

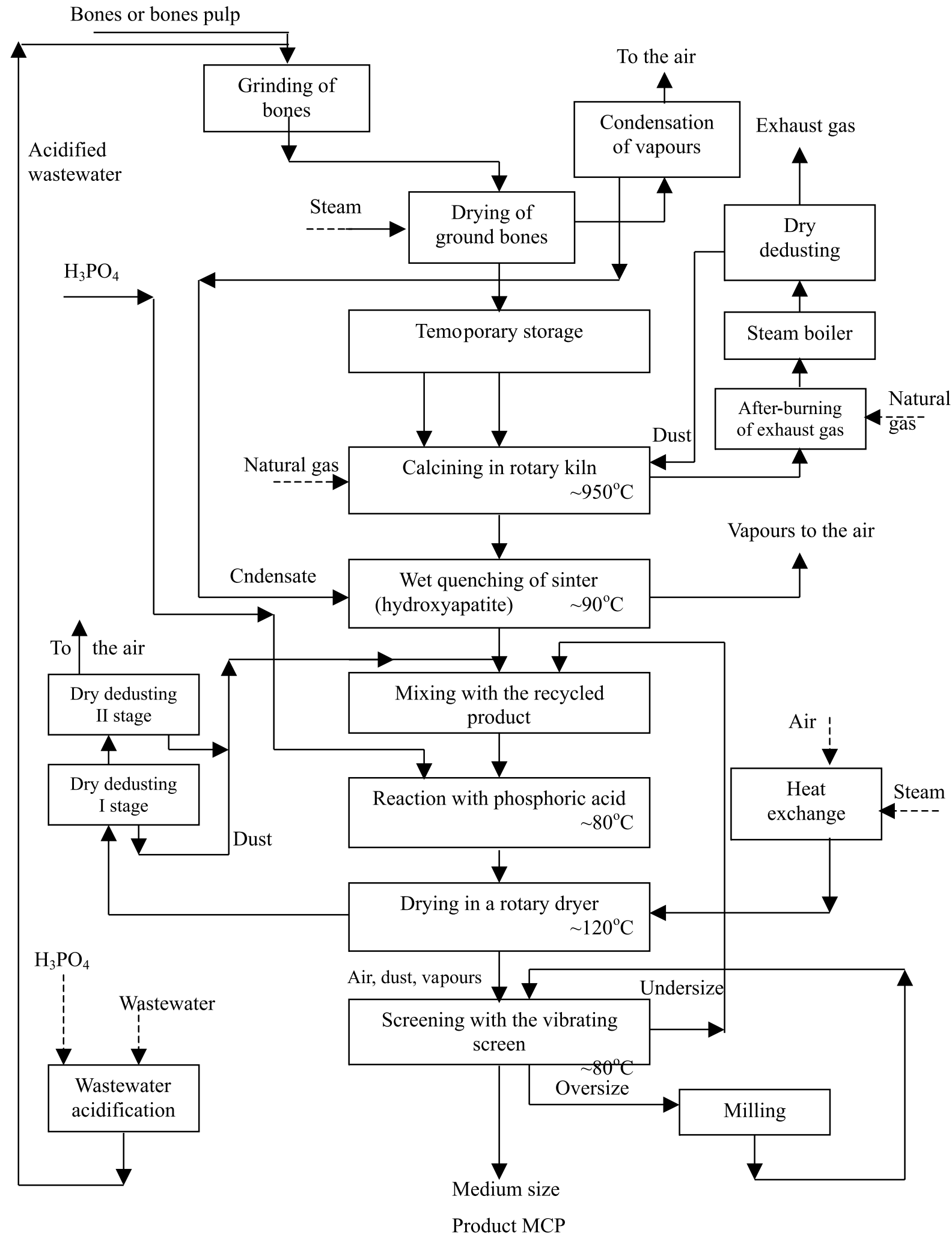

Figure 4. The flow sheet of the waste bones thermal utilisation unit and the production from the hydroxyapatite obtained from the MCP feed phosphate 
Table 2. The production of hydroxyapatite and phosphoric acid from meat waste in Poland

\begin{tabular}{|c|c|c|c|c|c|}
\hline \multirow{2}{*}{ Waste and by-products } & \multicolumn{3}{|c|}{ Quantity [per 1 year] } & \multicolumn{2}{|c|}{ Product [t/y] } \\
\hline & [ton] & $\begin{array}{l}\text { Equal to } \\
\text { [GJ] }\end{array}$ & $\begin{array}{c}\text { Equal to [mln cm] of natural } \\
\text { gas }\end{array}$ & $\mathrm{HA}$ & $\mathrm{H}_{3} \mathrm{PO}_{4}$ \\
\hline Bone waste & 125356 & & & 50142 & 23877 \\
\hline Other meat waste & 818840 & & & & \\
\hline Meat bone meal MBM & 327536 & & & 81884 & 38992 \\
\hline Fat from MBM production* & 163768 & 6386951 & 190 & & \\
\hline Total & & & & 132026 & 62870 \\
\hline
\end{tabular}

${ }^{*}$ total sale; HA -hydroxyapatite

Off-process recycling of meat waste

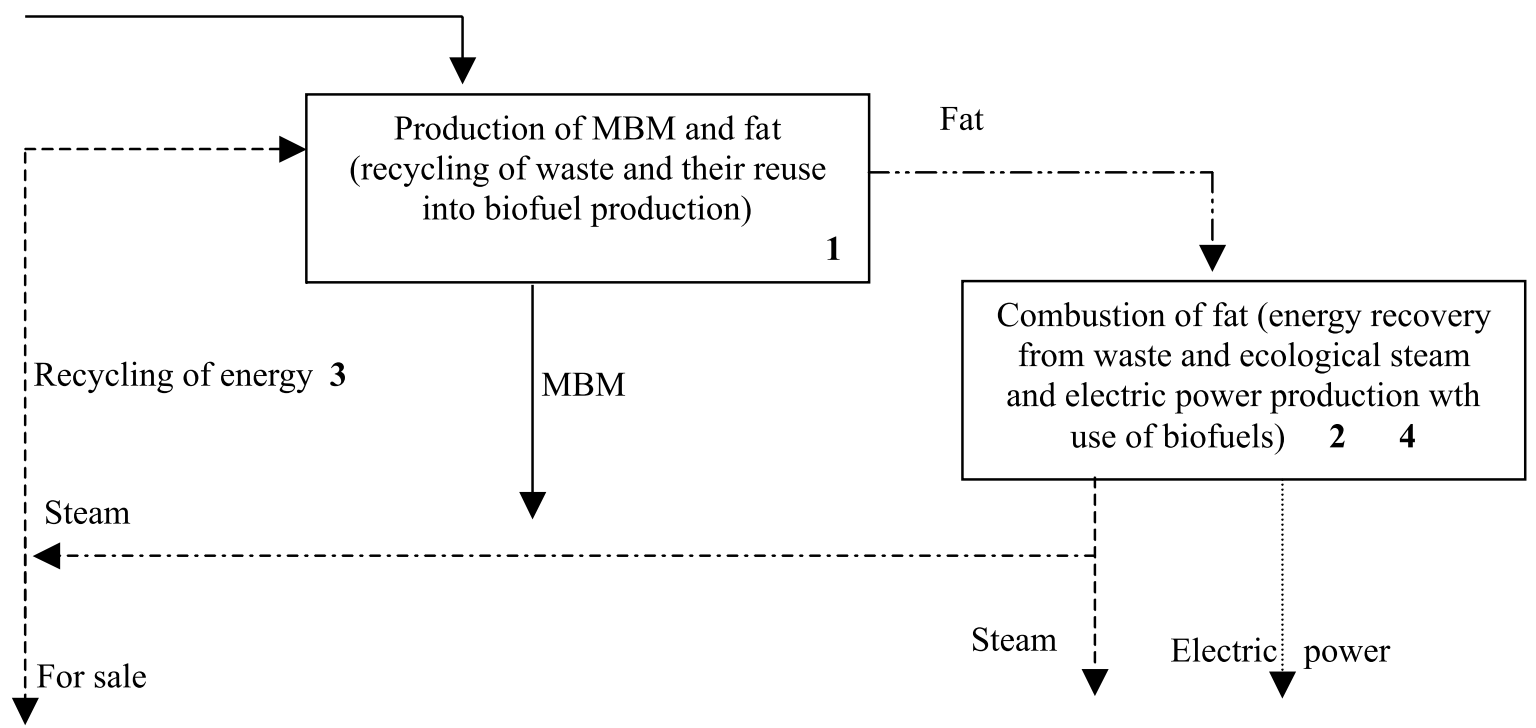

Figure 5. The diagram of materials and energy streams connections for the existing production lines. Cleaner production elements: 1 - meat waste off-process recycling, processing and reuse of waste, bio fuel (fat) recovery from meat waste; 2 - energy recovery from the waste (bio fuel); 3 - in-process recycling of heat energy

pressure $0,26-0,3 \mathrm{MPa}$. The boiling bones are separated with the help of the screens from the solution that is next cleaned in a decanter where the bone pulp is precipitated. The fat is separated from the hydrolysate with centrifugal separation. The products are as follows ${ }^{\mathbf{7}, 21,22}$ :

- Proteins hydrolysate contained [\%w/w] $96.08-88.48$ of water; $3.84-11.44$ of proteins, $0.05-0.09$ of fat.

- technical animal fat contained [\%w/w] 95.17 of fat and 4.83 of water with the density $0.8 \mathrm{~kg} / \mathrm{dm}^{3}$ and the melting temperature $\sim 50^{\circ} \mathrm{C}$

- Bone dense pulp with the rest of proteins and fat demonstrating dark-grey colour contained [\%w/w] 64.55 of water; 19.0 of fat; 11.50 of proteins; 4.95 of mineral substances, with the $0.795 \mathrm{~kg} / \mathrm{dm}^{3}$ density.

- Bone fragments, the post boiling residue contained [\%w/ w] 33.1 of water; 3.20 of fat; 20.0 of proteins; 43.70 of mineral substances with the density of $0.853 \mathrm{~kg} / \mathrm{dm}^{3}$.

Gelatine production is some kind of an alternative for obtaining different proteins, hydrolysate grades and technical fat. The technology is well known ${ }^{23-25}$. The proposed concept includes a new solution making the gelatine production waste free due to the utilization of wasted brine into meat processing. The raw materials contain collagen proteins ground pigs and cattle bones or skin, hydrochloric acid, sodium hydroxide. The produced low temperature gelatine is tightly gelated (three basic grades, liquid or powder). The by-products for the utilisation are bone fragments, bone pulp and brine. The technological process includes bone grinding, washing the ground bones with hot water and fat recovery from it, maceration of the ground bones with hydrochloric acid, filtration of the solution from maceration, neutralization of hydrochloric acid with sodium hydroxide. Other operations are transportation of material after maceration, production of proteins hydrolysate, sedimentation of hydrolysate slurry in the decanter, its concentration and spray drying.

\section{Recovery of fat from meat and bone waste}

Fat could be recovered from meat waste in the abovementioned processes and also in the production of meat bone meal from animal waste ${ }^{\mathbf{3 , 2 6}}$. A method of fat recovery from the post-flotation waste and its use as fuel, substitute of natural gas was proposed to one of the meat factories. The quantity of such waste, containing the maximum $15 \%$ of fat, amounted to $12,750 t / y e a r$. The recovery of $90 \%$ of fat contained in the waste allowed obtaining 1,721t/year of fat. The recovered fat could be sold as a technical grade or used as the fuel substitute of natural gas ${ }^{3}$. The preliminary balance and economic evaluation showed that a possible decrease in production costs could amount to 1,59 PLN million per year, resulting from the use of the recovered fat as bio fuel, the substitute of natural gas.

\section{Thermal utilisation of waste and by-products from meat industry}

Meat, bone and slaughter waste could be thermally utilized. The realized calcining test of bone pulp in the laboratory chamber kiln at $600-950^{\circ} \mathrm{C}$ resulted in the possibility of thermal utilisation of bone waste. The produced ash contained practically pure hydroxyapatite with low quantities of silica, 


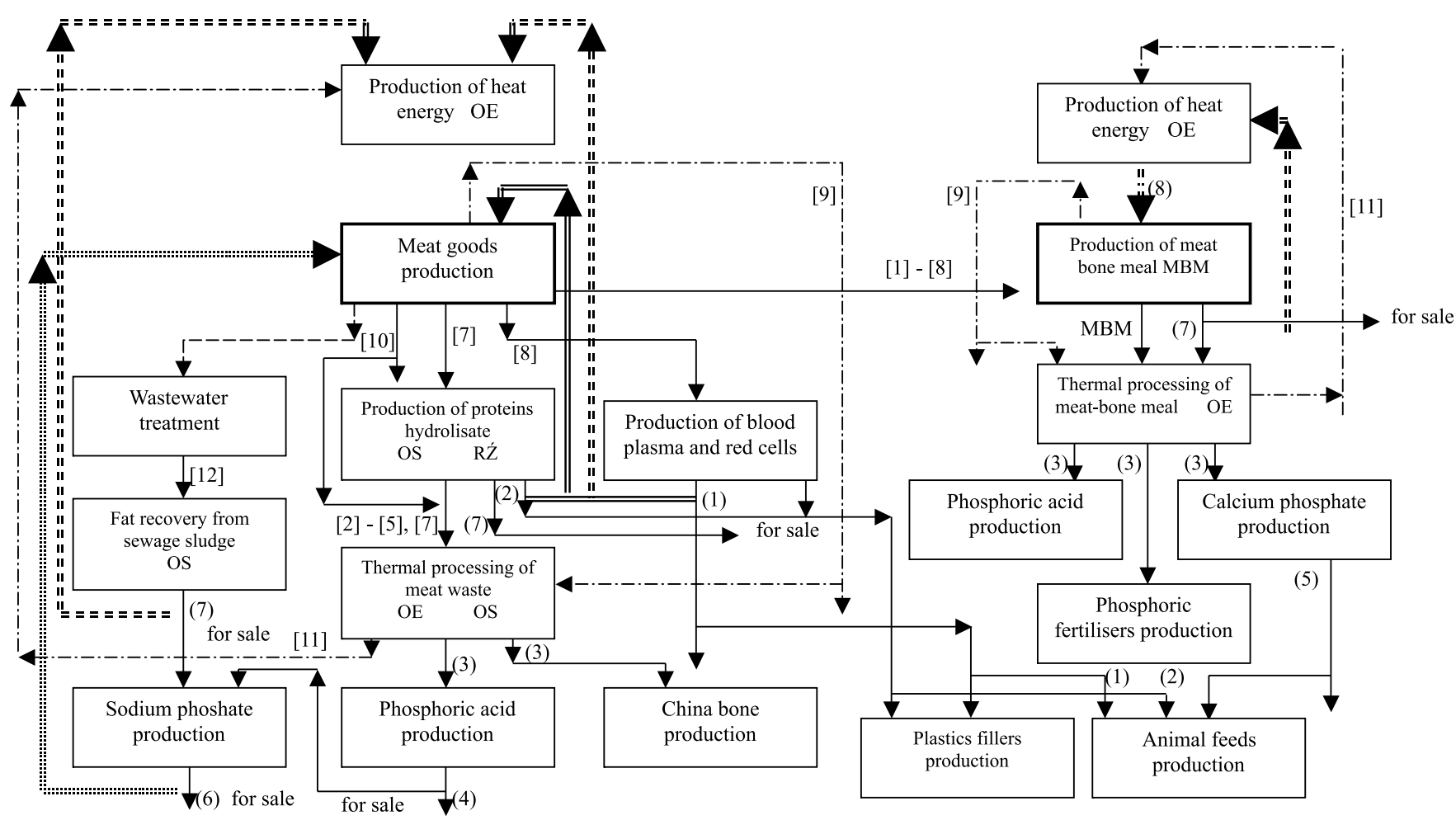

Figure 6. The target model of the meat waste management; RZ - reduction at source, OE - energy recovery, OS - raw materials recovery; Waste and by-products types: [1] dead animal, [2] bone waste, [3] wasted meat products and raw materials, [4] wasted tin issue (soft), [5] by-products from the slaughter processes, feed system content, [6] hoofs, horns, nails, feather,[7] bone by-products, [8] blood, [9] vapours and odours, [10] wastewater [11] exhaust gases, [12] sewage sludge Products types: (1) plasma, (2) red cells, (3) hydroxyapatite, (4) phosphoric acid, (5) calcium phosphate, (6) sodium phosphate, (7) fat, (8) steam; Solid products and waste ----- Liquid products and waste

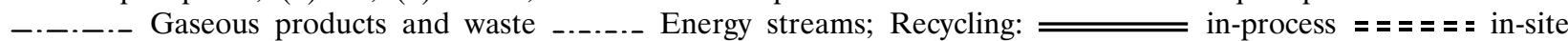

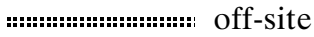

aluminium and sodium. In the ash calcining at $950^{\circ} \mathrm{C}$ the phosphorus content was $16,5 \%$ and calcium $39,3 \%$. The Xray analysis showed that hydroxyapatite was the main crystal phase. The ash was the homogenous raw material from the physical and chemical properties point of view, rather pure with a very low content of heavy metals ${ }^{7,27-30}$. Up to now the research results have shown that all types of meat wastes and by-products could be thermally utilized and produce, with the proposed method, the ashes containing nearly pure calcium phosphate. Hydroxyapatite $\mathrm{Ca}_{5}\left(\mathrm{PO}_{4}\right)_{3} \mathrm{OH}$ could be used as raw material in phosphoric acid production ${ }^{\mathbf{3 1}, 32}$ and the mono- or dicalcium feed phosphates $\mathrm{CaHPO}_{4}$, $\mathrm{Ca}\left(\mathrm{H}_{2} \mathrm{PO}_{4}\right)_{2}$. Figure 4 presents the flow sheet of the thermal utilisation of bone waste and the production of monocalcium phosphate MCP from the obtained hydroxyapatite $\mathrm{MCP}^{33}$.

\section{A new solution in meat bone meal production on the exam- ple of the Farmutil firm}

A strategic program of Farmutil was based on the new approach to environmental problems and their connection with industry. The advantage of this firm is a diversified production complex that could potentially utilise all the energy recovered from the meat waste processing ${ }^{2,34}$. Elimination of odour emission is very important for Farmutil's image. The implementation in 2005 of the thermal method of odours removal from the production of meat bone meal considerably improved the air quality ${ }^{2}$. It is possible to realize in this company the complex waste management and cleaner technologies were used successfully in the production. Figure 5 presents the diagram of materials and energy flows for the existing production lines using the cleaner production elements.

\section{TARGET MODEL OF MEAT WASTE MANAGEMENT}

The proposed solution is presented in Figure 6 as a model of the flows of materials, energy and waste properly connected. The model proposes pollution prevention with a reduction of some waste quantities and their reuse, raw materials and energy recovery, substitution of natural raw materials with waste, thermal processing of meat waste and by-products and their utilization as bio fuels.

The research works on the utilization of dried plasma and proteins, as the fillers in plastics production have been continued $^{\mathbf{3 5}}$. The further realized research applies the use of dried proteins and plasma as feed additives ${ }^{\mathbf{3 6}, 37}$. Energy recovery from meat waste has been implemented and production of technical fat, too. The proposed model provides the implementation of the above mentioned thermal methods of meat waste processing and the use of the produced ashes as raw materials in the production of phosphoric acid, sodium phosphates used in food preservation or calcium feed phosphates. Meat bone meal could be used as a valuable bio fuel and the ash from its calcining could also be used in the phosphoric acid production ${ }^{38,39}$. The vapours from meat industry (smoke from the curing house or odours) have been thermally processed ${ }^{31,34}$.

The proposed target solution of the meat waste management should solve the meat waste problem and the production of phosphorus compound on their base. The energy (bio fuels) recovery from this waste could also turn out to be 
significant. The recovered fat should practically substitute all the natural gas used in the steam production in meat factories.

\section{LITERATURE CITED}

(1) Wilkosz-Język A.: Otrzymywanie fosforanu wapnia z mączki mięsno-kostnej, Praca doktorska, Politechnika Krakowska, 2007.

(2) Kowalski Z.: Odpady mięsne a emisja odorów, Przegląd Komunalny, 2007, 1(184), 52

(3) Kowalski Z., Konopka M., Krupa-Żuczek K., Wilkosz A.: Animal Fat Recovery from Meat and Postflotation Waste and their Use as Substitute of Natural Gas, 10th Conference on Environment and Mineral Processing, VSB-TU Ostrava, Czech Republic 22-26.06.2006, 271.

(4) Kowalski Z., Kulczycka J.: Cleaner production as a basic element for the sustainable development strategy. Polish Journal of Chemical Technology 2004, 6, 4, 35

(5) Cleaner production and the Cleaner Production Program UNEP Industry and Environment, October - December, Paris, 1994.

(6) Czaja S.: Analiza zgodności funkcjonujących w Polsce elementów fiskalnych $\mathrm{z}$ celami Zintegrowanej polityki produktowej, AE Wrocław 2003 (not published).

(7) Krupa-Żuczek K.: Otrzymywanie kwasu fosforowego ze szlamów kostnych z przemysłu mięsnego, Praca doktorska, Politechnika Krakowska, 2007.

(8) Steen I.: Phosphorus availability in the 21st century: Management of a non-renewable resources, Phosphorus and Potassium. 217, 1998, 25-30

(9) Poskrobko B.: Zarządzanie środowiskiem, Polskie Wydawnictwo Ekonomiczne, Warszawa, 1998.

(10) Kowalski Z., Kulczycka J.: Management of animal waste. Conference on Industrial Pollution and Sustainable Development, University of Maribor Slovenia, 14-17 December 2005.

(11) Rozporządzenie Rady Europy (WE) Nr 999/2001.

(12) Dyrektywa Rady 86/609/EEC z dnia 24 listopada 1986 o ujednoliceniu ustaw, rozporządzeń administracyjnych Państw Członkowskich dotyczących ochrony zwierząt używanych do celów doświadczalnych i innych celów naukowych.

(13) Rozporządzenia Parlamentu Europejskiego i Rady UE 1774/2002 z 3 października 2002.

(14) Dyrektywa Rady Europy 96/23/WE z 28 kwietnia 1996 dotycząca środków nadzorowania pewnych substancji i ich pozostałości w żywych zwierzętach i wyrobach pochodzenia zwierzęcego.

(15) Wandrasz A. J., Wandrasz A. Z.: Badanie składu elementarnego i właściwości kalorycznych produktów zwierzęcych, Materiały V Międzynarodowej Konferencji „Paliwa z odpadów”, Wyd. Helion, Gliwice 2005, 225.

(16) Cholewa J., Prorok W., Balisz J., Bajcer T., Klamecka A., Klamecki G.: Założenia technologiczne dla produkcji plazmy metodą wirowania krwi, PPHU Duda-Bis Sosnowiec, 2004 (not published).

(17) Silva V. D. M., Silvestre M. P. C.: Functional properties of bovine blood plasma intended for use as a functional ingredient in human food, Lebensmittel Wissenschaft und Technologie, 2003, 36, 709.

(18) Weir G. S. D. in Hudson B. J. F.: (Editor), Developments in Food Proteins, vol. 4, Elsevier Applied Science Publishers, New York 1986, 175.

(19) Damodaran S. in Nakai S., Modler H. W.: (Editor), Food Proteins - Properties and Characterisation, VCH, New York 1996, 167.

(20) Adler-Nissen J.: Enzymatic Hydrolysis of Food Proteins, Elsevier, New York 1986.
(21) Konopka M., Kowalski Z., Fela K., Cholewa J., Bajcer T.: Charakterystyka niskotemperaturowego procesu otrzymywania protein na bazie tkanki mięsno-kostnej $z$ zastosowaniem enzymów. Recyclace Odpadu X, VSB Ostrava, Czech Republic, 03.11.2006, 311.

(22) Konopka M., Kowalski Z., Cholewa J.: Decolorization of protein hydrolysates from deproteinase of bone waste with use of hydrogen peroxide. Chemistry and Biochemistry in the Agricultural production, Environmental Protection, Human and Animal Health. Chemistry for Agriculture, Vol. 7, Czech-Pol Trade, Jesenik, Czech Republic, 2006, 742.

(23) Pezacki W.: Przetwarzanie niejadalnych surowców rzeźnych, PWN Warszawa,1987.

(24) Wybór W., Zaborski M.: Budowa i własności kolagenu, oraz żelatyny. Polimery 2000, 45, 1, 10.

(25) Rutkowski A.: (Editor), Żelatyna. Właściwości technologia - użytkowanie, Polska Izba Dodatków do Żywnosci, Wyd. Apeks, Konin, 1999.

(26) Cholewa J., Kowalski Z.: Koncepcja wykorzystania tłuszczu z odpadów poflotacyjnych jako zamiennika gazu ziemnego, PPUH Duda-Bis, Sosnowiec 2005 (not published).

(27) Krupa -Żuczek K., Wilkosz A., Wzorek Z.: Receiving phosphoric acid from meat industry waste. Polish Journal of Chemical Technology, 2004, 1, 161.

(28) Wzorek Z., Lenik E., Gorazda K.: Popioły ze spalania odpadów z przemysłu mięsnego i osadów ściekowych jako źródło fosforu, Materiały V Międzynarodowej Konferencji „Paliwa z odpadów”, Wyd. Helion, Gliwice 2005, 135.

(29) Kowalski Z., Wzorek Z., Cholewa J., Krupa -Żuczek K.: Instalacja do wytwarzania związków fosforu na bazie tkanek mięsno-kostnych i kwasów mineralnych dla P.P.H.U. Duda-Bis w Sosnowcu, Część I - Projekt Technologiczny, Sosnowiec 2004, (not published).

(30) Krupa - Żuczek K., Wilkosz A., Wzorek Z.: Receiving phosphoric acid from meat industry waste, 1st International Seminar, Modern Polymeric Materials for Environmental Application, Krakow 16-18 December 2004, 157.

(31) Kowalski Z., Wzorek Z., Cholewa J., Krupa -Żuczek K.: Koncepcja technologiczna wytwarzania związków fosforu na bazie tkanek mięsno-kostnych i kwasów mineralnych, Politechnika Krakowska 2004, (not published).

(32) Technologia związków fosforu. Praca zbiorowa, WNT Warszawa, 1958.

(33) Wilkosz A., Krupa - Żuczek K., Konopka M., Wzorek Z.: Produkcja fosforanu jednowapniowego na bazie odpadów z przemysłu mięsnego, VI Konferencja Technologie Bezodpadowe i Zagospodarowanie Odpadów w Przemyśle Chemicznym i Rolnictwie (streszczenia), Międzyzdroje 2004, 223.

(34) Kowalski Z., Wzorek Z., Konopka M., Banach M.: Możliwość eliminacji odorów w ramach wdrażanie rozwiązań czystszej produkcji w FARMUTIL HS, Ekotechnika, 2007, 1,41, 34.

(35) Zaborski M., Lipińska M.: Właściwości kauczuku zawierającego jako napełniacz strącaną kredę modyfikowaną aminokwasami. Polimery 2002, 47, nr 6, 429.

(36) Jamroz D.: Określenie chemicznych i funkcjonalnych właściwości produktów przerobu krwi i kości wieprzowych; możliwości ich zastosowania w żywieniu zwierząt monogastrycznych - drobiu. Akademia Rolnicza Wrocław, 2006 (not published).

(37) Podkówka W.: (Editor), Żywienie zwierząt i paszoznawstwo, PWN Warszawa, 2001.

(38) Wilkosz A., Krupa-Żuczek K., Wzorek Z.: Possibilities of use of bone meal in the chemical industry, Polish Journal of Chemical Technology, 2004, 6, 3, 39.

(39) Wilkosz A., Kowalski Z., Wzorek Z.: Określenie możliwości spalania mączki mięsno-kostnej. Materiały V Międzynarodowej Konferencji „Paliwa z odpadów”, Wyd. Helion, Gliwice 2005, 295. 